\title{
The triumph of disease?
}

Richard Davenport-Hines

Miasmas and Disease: Public Health and the Environment in the Pre-Industrial Age. By Carlo M. Cipolla. Yale University Press: 1992. Pp. 101. \$25, £16.95. The Fourth Horseman: A Short History of Epidemics, Plagues and Other Scourges. By Andrew Nikiforuk. Fourth Estate: 1992. Pp. 200. £14.99.

TRIUMPHALISM has marred medical history throughout this century. For years, the subject was presented as an accompaniment to the March of Progress. Heroic scientists and humane physicians were depicted in an unceasing and unselfish battle against disease. The benefits of new therapies and vaccines were hailed: Nobel laureates such as Ehrlich were celebrated in Hollywood films, their discoveries taken as a sign that mortality could be postponed. Fifteen years ago, medical historians began to react against these simplifications. Physiological factors have lost their paramountcy. Scientific careerism is recognized. Both disease and the mediation of physicians have been increasingly analysed in the context of patients' social environment. This revisionism has brought many benefits, but can go miserably awry.

Revisionist techniques are exemplified at their best by the distinguished polymath Carlo Cipolla. His monograph is based on the records of the Florentine Health Board in the early seventeenth century, an epoch when Italy was at the forefront of European public health organization. He reproduces extracts from original medical reports that show the efforts of intelligent, inquisitive and eager physicians to fight disease in an unhygienic, superstitious culture. In addition, he provides interesting insights into the economic consequences of epidemics. Quarantine brought economic ruin to many communities, and when malaria was not fatal, its weakening of patients was a determining factor in economic stagnation and long-term poverty.

The rural masses of Tuscany were deterred from seeking medical treatment by poverty and because, as Cipolla writes, "physicians inspired feelings of reverent fear and peasants preferred to consult the local charlatan or wise woman". Given the failure of medical techniques, this preference probably saved peasant lives. As one physician reported in 1622, "more of those who are able to seek medical advice and treatment die than of the poor". Cipolla describes his story as "sad, unpleasant and often tragic". He writes with humanity, humility and scrupulous care, not least of physicians whose knowledge now seems woefully limited.

By contrast, Andrew Nikiforuk's derivative and journalistic diatribe on epidemiology is arrogant, indignant and contemptuous. "One of the great lies of the twentieth century", he trumpets, is "that antibiotics, vaccines and doctors have saved us from pestilence." For the triumphalism of scientists conquering

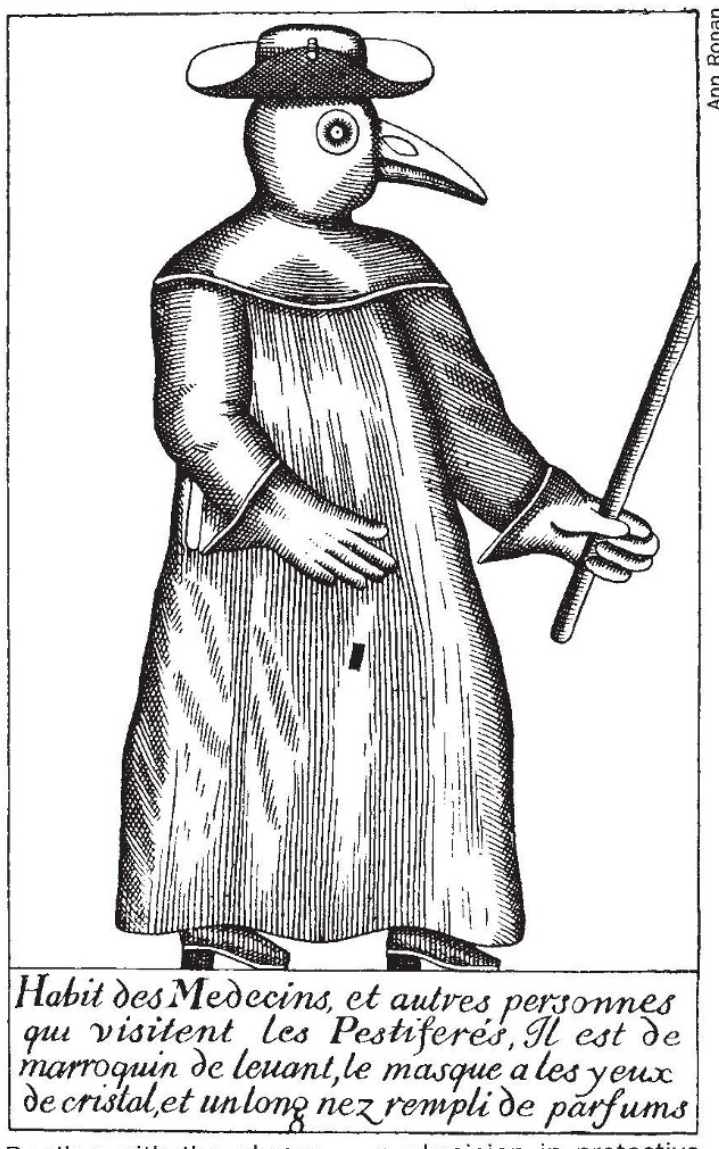

Dealing with the plague - a physician in protective clothing (from an eighteenth-century illustration).

microbes, he substitutes a hegemony of disease - what he calls "the golden age of pestilence". Bacteria are described as the planet's "eldest, brightest" life-form working together "as one big superorganism" and erupting in epidemics when humankind has "trampled its frontiers violating unwritten bacterial codes".

He seems more in sympathy with the 'superorganism' than with humans. His comments on his fellow beings vary from obtuseness to lofty cruelty. In the past, he writes in apparent admiration, "people didn't marry for sex or looks; they carefully chose a partner for his or her ability to outlive an epidemic" as if two millennia of erotic literature were a lie, and as if human emotions could be reduced to the eugenic equations beloved by twentieth-century totalitarianism.

In a key section he deprecates the more recent "obsessive desire to eradicate malaria" as "appalling" in its "racial, economic and political consequences". The elimination of malaria in Sri Lanka, for example, has led to overpopulation, which made civil war inevitable. "When people tinker with malaria", he moralizes, "they ultimately tinker with the structures of everyday life." If his argument has any meaning, it is that high mortality from malaria should be perpetuated in underdeveloped economies. Readers of Cipolla's account of the effects of malaria will recoil from the brutality of this.

Nikiforuk makes some fair points about the ecological destruction of the planet, and has legitimate criticisms of some medical practices, but his opposition to human meddling with "the total environment" is fanatical. Moreover, his ostensible concern with ecology frequently turns into righteous denigration of human choice - or "life-style" in the cant upon which he relies. "The passion for setting people right is in itself an afflictive disease", as Marianne Moore wrote. Nikiforuk's passion becomes pathological in his final chapter, a highly tendentious account of AIDS. He insists on false distinctions between the spread of the human immunodeficiency virus (HIV) in Africa and what he does not scruple to call the "gay plague" in the United States. Male homosexuality is "biological suicide", people with AIDS are "young middle-class men who thought they could defy biology" and HIV poses no threat to "white middle-class couples". Nikiforuk lingers in detail on sexual acts that he abhors, and becomes imaginatively overheated in places. Every paragraph of this chapter contains an assertion that could be contested, or a sentiment that repels.

The peculiarities of this unpleasant book go far beyond quaint eccentricity. It insults honest, if fallible, scientists and physicians. Patients are patronized and degraded. The chapters on malaria and HIV are a farrago of specious assertions and authoritarianism. Overall The Fourth Horseman is a discredit to environmentalism and a travesty of historical truth.

Richard Davenport-Hines is at 51 Elsham Road, London W14 8HD, UK. 